\title{
WOMEN IN ENGINEERING
}

\author{
Pratibha Dharmavarapu $^{1}$, Pooja Angolkar ${ }^{2}$ \\ ${ }^{1}$ Department of Mechanical Engineering, Anurag Group Of Institutions, Hyderabad \\ ${ }^{2}$ Department of Mechanical Engineering, Anurag Group Of Institutions, Hyderabad \\ ${ }^{1}$ prathibha.d@gmail.com \\ 221pooj@gmail.com
}

\begin{abstract}
Women comprise more than $20 \%$ of engineering school graduates, yet only $11 \%$ are practicing engineering, despite decades of academic, federal, and employer interventions to address this gender gap.

Women who are highly confident of their abilities to manage multiple life roles and navigate the political climate at work are most likely to want to stay with their career. Further, women who expect positive outcomes from their successful performance of engineering tasks are less likely to consider leaving the job, as it is a booster to them to pursue their career in the choice of their engineering fields. Also, they are considered by the organization vice versa, as they may not be the primary source of income to their respective families.

Women who have supportive co-workers are more successful compared to the ones who have no support including domestic support. Also, the companies who are requiring skilled professionals provide them with training and development opportunities. Such kind of women is less likely to leave engineering.

Women are more likely to be committed to the field of engineering if they receive opportunities for training and development, opportunities for advancement and believe that time demands are reasonable. Women are more likely to be committed to their engineering job when their companies value their contributions and having worked with supportive co-workers. Women must be encouraged to pursue their career and attain their goals in engineering. Also, as part of any organization, the contribution of any woman must also be encouraged. The paper discusses some suggestions or steps to be taken to encourage women to continue or start their careers in engineering as their choice.
\end{abstract}

Keywords: women, engineering, career, employer, organization.

\section{PratibhaDharmavarapu}

Department of Mechanical Engineering, Anurag Group Of Institutions, Hyderabad prathibha.d@gmail.com

\section{INTRODUCTION}

Women are often under-represented in the fields of engineering, both in academics and as a profession. A number of organizations and programs have been created to understand and overcome this tradition of gender disparity. Women have contributed to the diverse fields of engineering in modern and historical times.

There are disparities within the undergraduate engineering degree. Of the observation made by experts Women are less likely to study mechanical, electrical, and aeronautical engineering than chemical or civil engineering. Astronauts and Indian KalpanaChawla and Sunitha Williams are the best Example of the women who have been successful in their careers as Engineers.

All explanations for women persisted difficultly are of two main kinds. One is about capital characteristics; another one is about gender difference. Stereotype threat includes gender identification, engineering identification and gender ability perceptions. Women inengineering experience difficulties related to the male-dominated aspects of engineering but women who persist are able to overcome these difficulties enabling them to findfulfilling andrewarding experiences in the engineering profession.

The problems for women to take up engineering as their career in the world:

1. Nature of work (shop floor work may not be preferred and may be rejected upfront by the women)

2. Level of work( junior level)

3. Gender disparity

4. In-equality

5. Domestic problems

6. Physical restrictions

In India, the participation of women in engineering was negligible till the early 1980s. It is only in the past 15 years that their enrolment has shown an increasing trend. This movement began first in the southern states and has gradually spread to other parts of the country. However, with the increase in numbers, 
women engineers are facing many problems in their careers. These problems need to be understood and

\begin{tabular}{|l|l|l|l|l|}
\hline$\frac{\text { LEVEL OF }}{\underline{\text { PERFORM }}}$ & $\begin{array}{l}\text { TECHI } \\
\text { ICAL } \\
\text { SKILI } \\
\text { S }\end{array}$ & $\begin{array}{l}\text { INTERPE } \\
\text { RSONAL } \\
\text { SKILLS }\end{array}$ & $\begin{array}{l}\text { CONF } \\
\text { IDEN } \\
\text { CE }\end{array}$ & $\begin{array}{l}\text { OVERA } \\
\text { LLL }\end{array}$ \\
\hline $\begin{array}{l}\text { Lesser than } \\
\text { men } \\
\text { engineers }\end{array}$ & 6 & 9 & 21 & 12 \\
\hline $\begin{array}{l}\text { Same as } \\
\text { men } \\
\text { engineers }\end{array}$ & 87 & 56 & 66 & 81 \\
\hline $\begin{array}{l}\text { Better than } \\
\text { men } \\
\text { engineers }\end{array}$ & 5 & 33 & 11 & 5 \\
\hline No response & 2 & 2 & 2 & 2 \\
\hline Total & 100 & 100 & 100 & 100 \\
\hline
\end{tabular}

analysed.

1. There was no freedom to express the choice of education.

2. Also, due to family financial status, women were not chosen to be given education as the first preference.

3. Availability of resources like knowledge hubs, internets (digital libraries), Libraries were meagre in early days after the independence.

4. Awareness of the importance of engineering education.

5. Early marriages.

The table explains the performance of 100 women in an organization, rated by their executives. We can observe that the percentage of women who are equal to the performance of men is more.

\section{SURVEY}

On average, $11 \%$ of engineering faculty are women and the percentage of leadership roles held by women is an average of 9\%. In 2011, the International Network of Women Engineers and Scientists (INWES) Education and Research Institute (ERI) held a national workshop, Canadian Committee of Women in Engineering (CCWE), to determine ways of increasing the number of women in the engineering field in Canada. CCWE identified a goal of increasing women's interest in engineering by 2.6 percent by 2016 to a total of 25 percent through more incentives such as through collaboration and special projects. The workshop identifies early education as one of the main barriers in addition to other factors, such as: "the popular culture of their generation, the guidance they receive on course selection in high school and the extent to which their parents, teachers and counsellors recognize engineering as an appropriate and legitimate career choice for women".

The woman-dominated majors of today are unsurprising to anyone who has attended a large university in the U.S.:

1. Health Professions (85\% women): nursing assistant, veterinary assistant, dental assistant, etc.

2. Public Administration (82\%): social work, public policy, etc.

3. Education (79\%): pre-K, K-12, higher education, etc.

4. Psychology (77\%): cognitive psychology, clinical psychology, etc.

Surprisingly, most of the STEM (Science Technology Engineering Mathematics) majors are doing well as gender disparity-wise. $40-45 \%$ of the degrees in Math, Statistics, and the Physical Sciences were conferred to women in 2012. Even better, a majority of Biology degrees in $2012(58 \%)$ were earned by women. This data tells us that we don't really have a STEM gender gap in the U.S. we have an ET (Engineering Technology) gender gap!

\section{Employer's point of view:}

(1) Women engineers cannot work on the shop floor. (Did not agree: 41 per cent; agreed somewhat: 43 per cent.)

(2) Women cannot take up jobs involving travel. (Did not agree: 51 per cent; agreed somewhat: 36 per cent.)

(3) Women engineers do not and cannot join male colleagues in informal groups and there is a certain amount of self-exclusion. (Did not agree: 57 per cent; agreed somewhat: 37 per cent.)

(4) Women cannot balance their work with their family as they would have to give priority to the children. (Did not agree: 39 per cent; agreed somewhat: 43 per cent.)

The executives were also requested to give their opinions on certain concerns that come up while interviewing women engineers for a job. (1) Nearly 60 per cent of the executives said that they were concerned that a woman engineer would get married and leave her job. (2) In contrast, over 70 per cent did not express concern about the fact that women engineers may need to go on maternity leave. (3) A majority of the executives (over 60 per cent) involved in the recruitment process did notseem to be aware of the legal

\section{JeÈr}


implications of women being questioned differently during an interview.

Recommendations:

- Invest in providing potential training and development themselves professionally.

- Communicate their goals, frame individual tasks and relate them to the big picture.

- Healthy workplace atmosphere.

- Create an organizational culture and set some ethics that values employees' contributions.

- Root out anti-social, uncivilized and undermining behaviors in the workplace; create a culture that respects all.

- Create a supportive network at work: supportive supervisors, co-workers, and mentors make a difference.

- Offer work-life initiatives that are embedded in family supportive cultures.

Engineers, particularly female engineers, can require support and flexibility to enable them to balance the pressures and expectations of a family and a career.

\begin{tabular}{|l|l|l|}
\hline $\begin{array}{l}\text { Flexibility or } \\
\text { support offered }\end{array}$ & $\begin{array}{l}\text { \% of } \\
\text { employers } \\
\text { offering this } \\
\text { flexibility }\end{array}$ & $\begin{array}{l}\text { \% of } \\
\text { respondent that } \\
\text { have taken up } \\
\text { flexibility }\end{array}$ \\
\hline Flexible hrs & $90 \%$ & $62 \%$ \\
\hline $\begin{array}{l}\text { Opportunity to work } \\
\text { remotely }\end{array}$ & $83 \%$ & Not asked \\
\hline $\begin{array}{l}\text { Opportunity to work } \\
\text { part-time }\end{array}$ & $97 \%$ & 15 \\
\hline $\begin{array}{l}\text { Opportunity to take } \\
\text { career } \\
\text { break/sabbaticals }\end{array}$ & $67 \%$ & $16 \%$ female \\
\hline $\begin{array}{l}\text { Opportunity to buy } \\
\text { additional leave }\end{array}$ & $63 \%$ & $34 \%$ \\
\hline $\begin{array}{l}\text { Paid employees } \\
\text { assistance couseling } \\
\text { for support service }\end{array}$ & $83 \%$ & Not asked \\
\hline
\end{tabular}

It is clear that flexibility is offered, but it is not widely taken up. This is despite the legislative backing for flexible working through the Employment Relations

\section{CONCLUDING REMARKS}

Women engineers are perceived as capable professionals with high potential. Such a response could be because of the general acceptance of 'women in engineering' as a ground reality. It could also be due to the anxiety of the executive respondents to be correct in responding to the questions. The opinions coming through the replies to certain other questions, however, indicate that many employers have some reservations about the concept of women participating in the engineering profession. This is to be expected. Any change in social values is a complex phenomenon and takes time. The studies show that changes are in the offing. It is now a matter of time.

Recruitment of women into engineering is low, with just 23 per cent of enrolled students being female. The preference of female students for particular specialisms is of interest and it isrecommended that work be undertaken to determine the reasons for thispreference so the marketing of engineering as a career can be improved.

Women in growing numbers are joining engineering in India and making significant dent but even then, it is at the lower side when compared with other disciplines of education. During 2010-11, their participation in engineering was around 28 per cent which is, though, higher than the share of women engineering students in USA (around 20 per cent) and Australia (around 14 per cent) but quite low when compared with other streams in India as science, medical and arts where the participation rate is around 50 percent.

Employers of engineers are largely supportive of their employees, as shown by over 80 per cent of the 30 employers offering flexible hours, the ability to work remotely, and the ability to work part-time. However, there has been little uptake of this flexibility despite the legislative backing for flexible working through the Employment Relations (Flexible Working Arrangements) Amendment Act 2007. As both academia and industry are aware of limitation of working with women engineers but at the same time, they have lately realized their plus points and industry wants to leverage on those plus points. They are taking affirmative action to enhance participation of women engineers to improve the gender ratio.

Female representation at senior levels remains an area for further improvement, although it is noted that this can only be achieved if the number of women entering and remaining in the engineering profession continues to increase. Further work is needed to support women in engineering so they can balance their work and domestic responsibilities.

\section{REFERENCES}

[1] Women in Engineering: A comparative study of barriers across Nations

[2] Sen, Amartya. "The Many Faces of Gender Inequality. "The New Republic (2001)

[3] Clinton Global Initiative. "Why Invest in Adolescent Girls?" Report found at http://www.clintonglobalinitiative.org/ourmeetings/PDF lactionareas/Why_Invest_in_Adolescent_Girlspdf [4] Thomson Reuters Foundation,G20 Poll 2012. More information can be found at http://www.trust.org/trustlaw/news/poll-canada-bestg20-country-to-be-a-woman-india-worst/ [5] http://www.trust.org/trustlaw/news/india-advancesbut-many-women-still-trapped-in-dark-ages/

[6] Women Engineers in India P P PARIKH, S P SUKHATME 
[7] AICTE (2002): 'Background Document, National Consultation on the Future of Technical Education in India', New Delhi, p 51.

[8]UGC (1999): Research and Development Statistics, Department of Science and Technology, Ministry of Science and Technology, Government of India, New Delhi.

[9] Department of Labor and IPENZ (2008). Engineers in the New Zealand Labor Market. Well. 